\title{
ANALISA KINERJA DAN PRIORITAS SISTEM DRAINASE DI KAWASAN KOTA BORONG KABUPATEN MANGGARAI TIMUR
}

\author{
Indradhi Lasmana1, Ludofikus Dumin ${ }^{2}$, Stefen Ndun $^{3}$, Joko Suparmanto $^{4}$
}

\begin{abstract}
Abstrak :
Banjir atau genangan di suatu kawasan terjadi apabila sistem yang berfungsi untuk menampung genangan itu tidak mampu menampung debit yang mengalir, hal ini akibat dari tiga kemungkinan yang terjadi yaitu : kapasitas sistem yang menurun, debit aliran air yang meningkat, atau kombinasi dari kedua-duanya. Perkembangan kota semakin hari semakin terus berkembang dan kebutuhan masyarakat akan ruang permukiman semakin tinggi sehingga berpengaruh terhadap ruang terbuka dan resapan air di wilayah Kota Borong. Analisis kinerja saluran drainase di kawasan wilayah Kota Borong menjadi suatu langkah penting guna mencari solusi dalam penanganan masalah banjir dan genangan yang ada.

Dari hasil identifikasi kondisi sistem drainase dan kawasan yang mengalami banjir dan genangan di Kota Borong Kabupaten Manggarai Timur terdapat 8 (delapan) titik yang menjadi prioritas penanganan yaitu kawasan pasar Borong, Pasar Borong/Terminal, depan Koramil Kota Borong, Jalan Srikaya (depan Masjid Kota Ndora), Jalan Srikaya (depan Kantor DPRD), Jalan Sukun (masuk dari jalan negara), Jalan Sukun (kampung bugis peji depan kios warga), Perempatan di Kampung Bugis. Hasil Analisis Kinerja sistem jaringan drainase di kawasan Kota Borong dengan berbagai kriteria diperoleh kondisi bangunan cukup. Hal ini terlihat pada persentase kondisi sistem jaringan drainase di masing-masing sub sistem, yaitu kondisi di DG1 $=63,53 \%$, kondisi di DG2 $=$ $66,50 \%$, konsisi di DG3 $=69 \%$, DG4 $=60 \%$, DG5 $=61,25 \%$, DG6 $=68.37 \%$, DG7 $=53,27 \%$ dan kondisi di DG8 $=60,71 \%$. Analisis Penentuan skala prioritas penanganan dan penentuan daerah prioritas wilayah pasar Borong mempunyai nilai yang paling tinggi yaitu 456.25, Pasar Borong/Terminal $=421.25$, Jalan Srikaya 351.25, Jalan sukun 237.5, Jalan Sukun Kampung bugis Peji 237.5 dan perempatan Kampung Bugis 237.5 dengan dilakukannya penanganan meliputi peninggian badan jalan, perbaikan kapasitas saluran dan elevasi saluran serta perlunya adanya bangunan-bangunan resapan.
\end{abstract}

Kata Kunci : Banjir, Genangan, Analisis Kinerja, Skala prioritas, Sistem drainase.

\section{PENDAHULUAN}

\section{Latar Belakang}

Banjir atau terjadinya genangan di suatu kawasan pemukiman atau perkotaan masih banyak terjadi di berbagai kota di Indonesia. Genangan tidak hanya dialami oleh kawasan perkotaan yang terletak di dataran rendah saja, bahkan dialami kawasan yang terletak di dataran tinggi. Banjir atau genangan di suatu kawasan terjadi apabila sistem yang berfungsi untuk menampung genangan itu tidak mampu menampung debit yang mengalir, hal ini akibat dari tiga kemungkinan yang terjadi yaitu : 
kapasitas sistem yang menurun, debit aliran air yang meningkat, atau kombinasi dari keduaduanya. Pengertian sistem disini adalah sistem jaringan drainase di suatu kawasan.

Demikian halnya dengan Kota Borong di Kabupaten Manggarai Timur, seiring dengan terus mingkatnya perkembangan kota dan meningkatnya perkembangan permukiman dalam kawasan kota mengakibatkan semakin kecilnya ruang terbuka dan daerah resapan air dalam kawasan. Perkembangan kota semakin hari semakin terus berkembang dan kebutuhan masyarakat akan ruang permukiman semakin tinggi sehingga berpengaruh terhadap ruang terbuka dan resapan air di wilayah Kota Borong.

Pada saat ini banjir dan genangan belum menjadi suatu kejadian yang membahayakan kawasan tersebut, tetapi tidak tertutup kemungkinan pada beberapa tahun mendatang kondisi ini dapat membahayakan, baik itu kawasan permukiman, kawasan perdagangan maupun kawasan lainnya yang dekat dengan kawasan banjir yang ada.

Oleh karena itu evaluasi kinerja saluran drainase di kawasan wilayah Kota Borong menjadi suatu langkah penting guna mencari solusi dalam penanganan masalah banjir dan genangan yang ada.

\section{Identifikasi Permasalahan}

Permasalahan banjir dan genangan di wilayah Kota Borong tentunya disebabkan oleh beberapa hal antara lain kondisi sistem drainase yang ada saat ini tidak mendukung perkembangan Kota Borong, Penanganan drainase yang masih bersifat parsial, Sistem drainase eksisting mengalami banyak masalah akibat tidak terpadunya sistem.

\section{Rumusan Masalah}

Permasalahan dalam penelitian ini dapat dirumuskan sebagai berikut: Apa penyebab banjir dan genangan, Bagaimana kinerja sistem drainase yang ada saat ini, Bagaimana penanganan banjir dan genangan di Kota Borong Kabupaten Manggarai?

\section{Tujuan dan Manfaat Penelitian}

Tujuan dari Penelitian ini adalah untuk mengetahui penyebab banjir dan genangan di sekitar kawasan Kota Borong serta mengevaluasi kinerja sistem jaringan drainase pada masing-masing sub sistem dan menyusun skala prioritas pembangunan/rehabilitasi jaringan drainase di kawasan Kota Borong Kabupaten Manggarai Timur.

Manfaat dari penelitian ini adalah membantu menyelesaikan masalah pada kinerja sistem jaringan drainase berdasarkan standar perencanaan drainase yang berkelanjutan serta meningkatkan perhatian pemerintah dan peran serta masyarakat dalam pengelolaan sistem drainase yang berkelanjutan.

\section{TINJAUAN PUSTAKA Sistem Jaringan Drainase}

Sistem jaringan drainase merupakan bagian dari infrastruktur pada suatu kawasan, drainase masuk pada kelompok infrastruktur air pada pengelompokan infrastruktur wilayah, selain itu ada kelompok jalan, kelompok sarana transportasi, kelompok pengelolaan limbah, kelompok bangunan kota, kelompok energi dan kelompok telekomunikasi (Grigg 1988, dalam Suripin, 2004).

Bagian infrastruktur (sistem drainase) dapat didefinisikan sebagai serangkaian bangunan air yang berfungsi untuk mengurangi dan /atau membuang kelebihan air dari suatu kawasan atau lahan, sehingga lahan dapat difungsikan secara optimal. Dirunut dari hulunya, bangunan sistem drainase terdiri dari saluran penerima (interseptor drain), saluran pengumpul (colector drain), saluran pembawa (conveyor drain), saluran induk (main drain) dan badan air penerima (receiving waters). Di sepanjang sistem sering dijumpai bangunan lainnya, seperti gorong-gorong, siphon, jembatan air (aquaduct), pelimpah, pintu-pintu air, bangunan terjun, kolam tando dan stasiun pompa. Pada sistem drainase yang lengkap, sebelum masuk ke badan air penerima air diolah dahulu pada instalasi pengolah air limbah (IPAL), khususnya 
untuk sistem tercampur. Hanya air yang telah memiliki baku mutu tertentu yang dimasukkan ke dalam badan air penerima, biasanya sungai, sehingga tidak merusak lingkungan (Suripin, 2004).

\section{Pola Jaringan Drainase}

Menurut Wesli (2008), sistem jaringan drainase terdiri atas beberapa saluran yang berhubungan sehingga membentuk suatu pola jaringan. Dari bentuk jaringan dapat dibedakan sebagai berikut ;

a) Pola siku adalah suatu pola dimana cabang membentuk siku-siku pada saluran utama biasanya dibuat pada daerah yang mempunyai topografi sedikit lebih tinggi dari pada sungai di mana sungai merupakan saluran pembuang utama berada di tengah kota.

b) Pola pararel adalah suatu pola di mana saluran utama terletak sejajar dengan saluran cabang yang pada bagian akhir saluran cabang dibelokkan menuju saluran utama. Pada pola paralel saluran cabang cukup banyak dan pendek-pendek.

c) Pola grid iron merupakan pola jaringan drainase di mana sungai terletak di pinggiran kota, sehingga saluran-saluran cabang dikumpulkan dulu pada saluran pengumpul kemudian dialirkan pada sungai.

d) Pola alamiah adalah suatu pola jaringan drainase yang hampir sama dengan pola siku, dimana sungai sebagai saluran utama berada di tengah kota namun jaringan saluran cabang tidak selalu berbentuk siku terhadap saluran utama (sungai).

e) Pola radikal adalah pola jaringan drainase yang mengalirkan air dari pusat sumber air memencar ke berbagai arah, pola ini sangat cocok digunakan pada daerah yang berbukit. f) Pola jaring-jaring, adalah pola drainase yang mempunyai saluran-saluran pembuang mengikuti arah jalan raya. Pola ini sangat cocok untuk daerah topografinya datar.

\section{Fungsi Drainase}

Menurut Ditjen Tata Perkotaan dan Perdesaan, dalam panduan dan petunjuk praktis pengelolaan drinase perkotaan (2003), pembangunan sistem drainase perlu memperhatikan fungsi drainase sebagai prasarana kota yang di landaskan pada konsep berwawasan lingkungan, fungsi drainase perkotaan dapat kita lihat seperti yang di uraikan dibawah ini menurut : a) Mengeringkan bagian wilayah kota dari genangan sehingga tidak menimbulkan dampak negative, b) Mengalirkan air permukaan kebadan air terdekat secepatnya, c) Mengendalikan kelebihan air permukaan yang dapat dimanfaatkan untuk persediaan air dan kehidupan akuatik, d) Meresapkan air permukaan untuk menjaga kelestarian air tanah.

\section{Konsep Sistem Jaringan Drainase yang Berkelanjutan}

Sampai saat ini perancangan drainase didasarkan pada filosofi bahwa air secepatnya mengalir dan seminimal mungkin menggenangi daerah layanan. Tapi dengan semakin timpangnya perimbangan air (pemakaian dan ketersediaan) maka diperlukan suatu perancangan draianse yang berfilosofi bukan saja aman terhadap genangan tapi juga sekaligus berasas pada konservasi air ( Sunjoto, 1987 ).

Konsep Sistem Drainase yang Berkelanjutan prioritas utama kegiatan harus ditujukan untuk mengelola limpasan permukaan dengan cara mengembangkan fasilitas untuk menahan air hujan. Berdasarkan fungsinya, fasilitas penahan air hujan dapat dikelompokkan menjadi dua tipe, yaitu tipe penyimpanan dan tipe peresapan ( Suripin, 2004 ) seperti disajikan pada Gambar 1. 


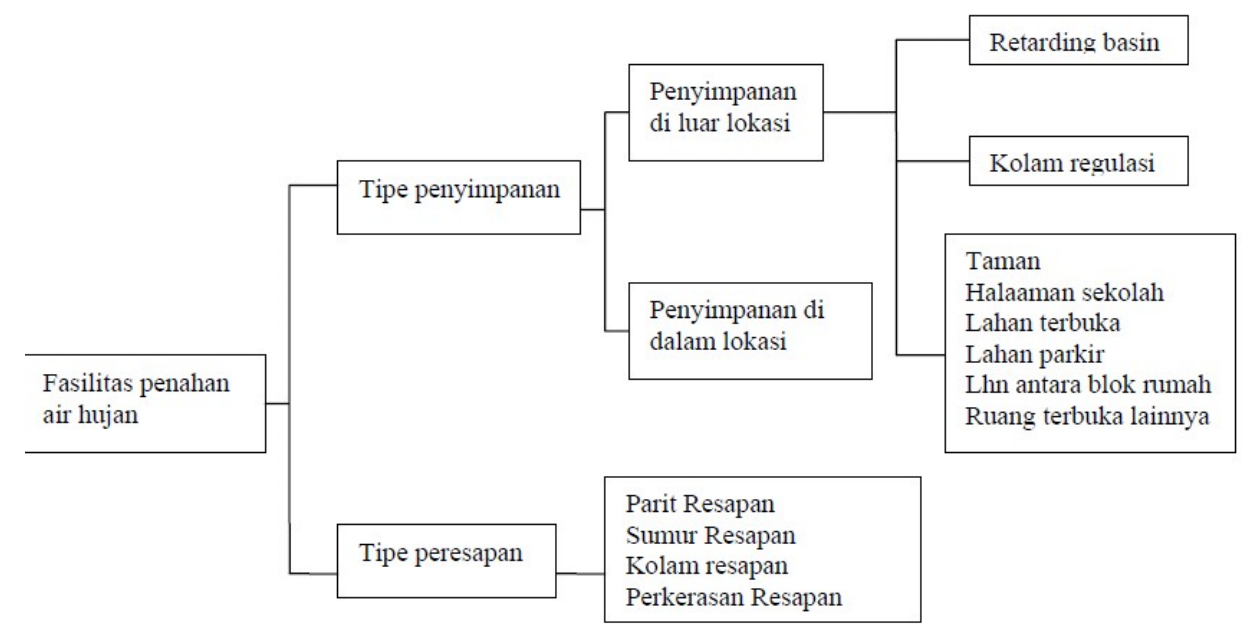

Gambar 1. Klasifikasi fasilitas penahan air hujan ( Suripin, 2004 )

Sedangkan menurut Sunjoto, 1987, konsepsi perancangan drainase air hujan yang berasaskan pada konsevasi air tanah pada hakekatnya adalah perancangan suatu sistem drainase yang mana air hujan jatuh di atap / perkerasan, ditampung pada suatu sistem resapan air, sedangkan hanya air dari halaman bukan perkerasan yang perlu ditampung oleh sistem jaringan drainase.

Pada penelitian ini langkah struktural dengan menggunakan tipe peresapan, Sumur Resapan Air Hujan ( RSAH ) seperti disajikan pada Gambar 2.2. dan Gambar 2.3.

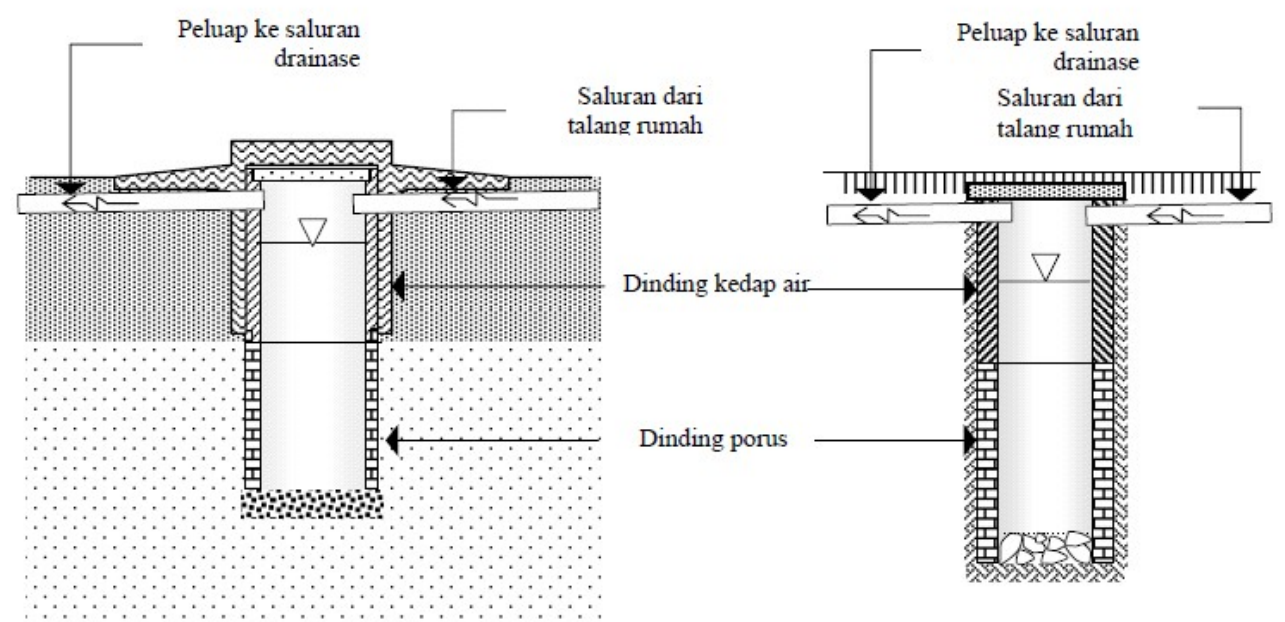

Gambar 2. Contoh Sumur Resapan Air Hujan ( Suripin, 2004 ) 


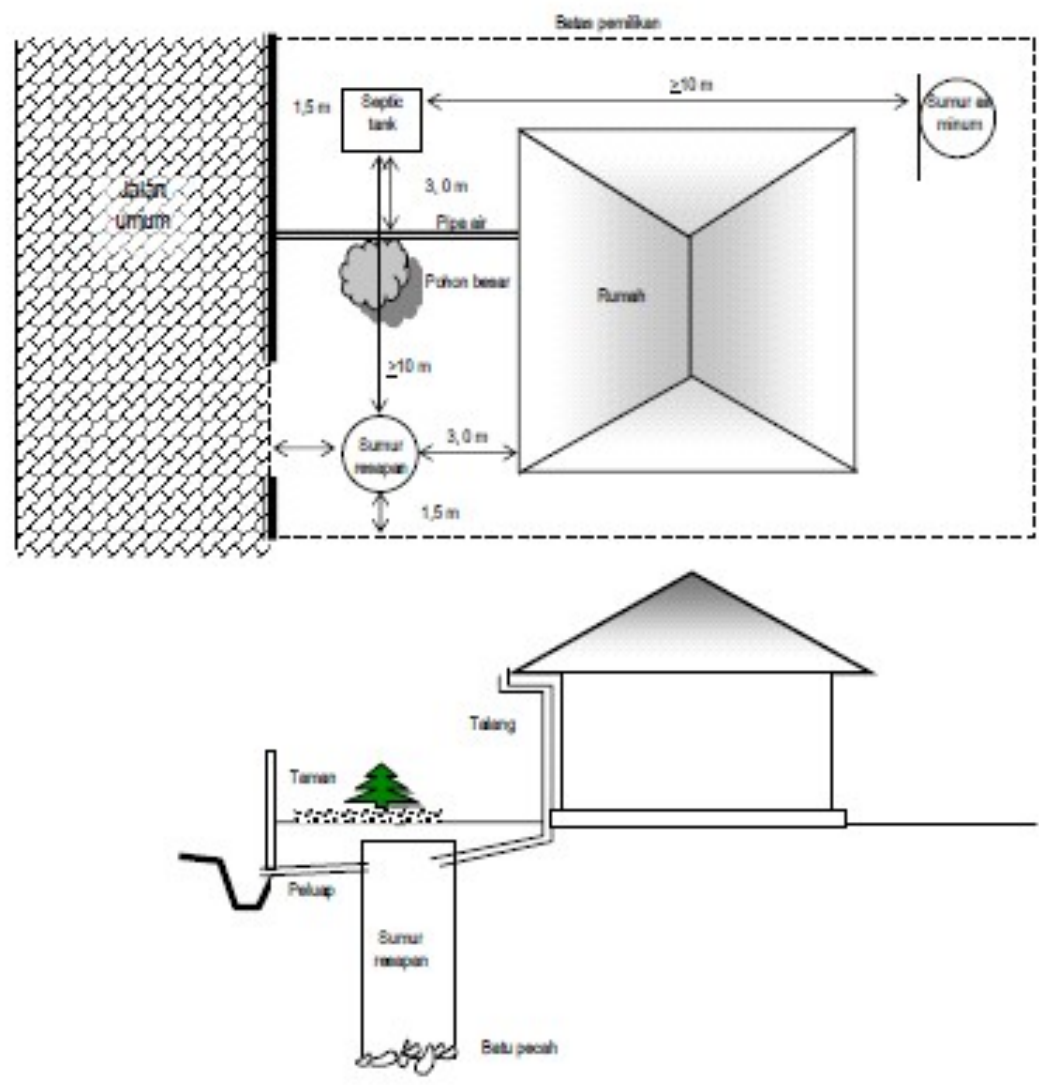

Gambar 3. Tata Letak Sumur Resapan Air Hujan ( Suripin, 2004 )

\section{Analisis Hidrologi}

Analisis hidrologi terdiri dari pengujian kelayakan data, analisis hujan daerah, analisis evapotranspirasi, perhitungan aliran rendah, dan Analisa kapasitas drainase. Semua perhitungan berdasarkan data-data dalam runtun waktu yang memadai. Data-data yang telah terkumpul perlu dilakukan penelitian (updating) agar mendekati gejala yang ada dilapangan.

\section{Parameter Penentuan Prioritas Penanganan Genangan}

Parameter penentuan prioritas penanganan meliputi hal sebagai berikut :

1.Parameter genangan, meliputi tinggi genangan, luas genangan, frekuensi genangan dalam satu tahun dan lama genangan terjadi.
2.Parameter ekonomi, dihitung perkiraan kerugian atas fasilitas ekonomi yang ada, seperti : kawasan industri, fasum fasos, perkantoran, perumahan, daerah pertanian dan pertamanan.

3.Parameter gangguan sosial dan fasilitas pemerintah, seperti : Kesehatan masyarakat, keresahan sosial dan kerusakan lingkungan dan kerusakan fasilitas pemerintah.

4.Parameter kerugian dan gangguan transportasi..

5.Parameter kerugian pada daerah perumahan 6.Parameter kerugian hak milik pribadi/rumah tangga. 
Lasmana ${ }^{1}$, Dumin $^{2}, \mathrm{Ndun}^{3}$, Suparmanto $^{4}$, Analisa Kinerja Dan Prioritas Sistem Drainase Di Kawasan Kota Borong Kabupaten Manggarai Timur

Tabel 1. Kriteria Parameter Genangan

\begin{tabular}{|c|c|c|c|}
\hline No. & Parameter Genangan & Nilai & Persentase Nilai \\
\hline 1 & $\begin{array}{l}\text { Tinggi Genangan } \\
>0,50 \mathrm{~m} \\
-0,30 \mathrm{~m}-0,50 \mathrm{~m} \\
-0,20 \mathrm{~m}-<0,30 \mathrm{~m} \\
-0,10 \mathrm{~m}-<0,20 \mathrm{~m} \\
-<0,10 \mathrm{~m}\end{array}$ & 35 & $\begin{array}{c}100 \\
75 \\
50 \\
25 \\
0\end{array}$ \\
\hline 2 & $\begin{array}{l}\text { Luas Genangan } \\
->8 \text { ha } \\
-4-8 \text { ha } \\
-2-<4 \text { ha } \\
-1-<2 \text { ha } \\
-<1 \text { ha }\end{array}$ & 25 & $\begin{array}{c}100 \\
75 \\
50 \\
25 \\
0\end{array}$ \\
\hline 3 & $\begin{array}{l}\text { Lamanya Genangan } \\
>8 \text { jam } \\
4-8 \text { jam } \\
2-<4 \text { jam } \\
1-<2 \text { jam } \\
<1 \text { jam }\end{array}$ & 20 & $\begin{array}{c}100 \\
75 \\
50 \\
25 \\
0\end{array}$ \\
\hline 4 & $\begin{array}{l}\text { Frekuensi Genangan } \\
\text { Sangat Sering (10 kali/tahun) } \\
\text { Sering (6 kali/tahun) } \\
\text { Kurang Sering ( } 3 \text { kali/tahun ) } \\
\text { Jarang ( } 1 \text { kali/tahun ) } \\
\text { Tidak Pernah }\end{array}$ & 20 & $\begin{array}{c}100 \\
75 \\
50 \\
25 \\
0\end{array}$ \\
\hline
\end{tabular}

Sumber : Tata Cara Penyusunan Sistem Drainase Kota 2011

Tabel 2. Kriteria Parameter Genangan

\begin{tabular}{|c|l|c|c|}
\hline No & \multicolumn{1}{|c|}{ Parameter } & Pengaruh/Kerugian & Nilai \\
\hline 1 & $\begin{array}{l}\text { Jika genangan air/banjir terjadi pada daerah } \\
\text { industri, daerah komersial dan daerah } \\
\text { perkantoran padat }\end{array}$ & Tinggi & 100 \\
\hline 2 & $\begin{array}{l}\text { Jika genangan air/banjir terjadi di daerah } \\
\text { industri dan daerah komersial yang kurang } \\
\text { padat. }\end{array}$ & Sedang & 65 \\
\hline
\end{tabular}




\begin{tabular}{|c|l|c|c|}
\hline 3 & $\begin{array}{l}\text { Jika genangan air/banjir mempengaruhi atau } \\
\text { terjadi di daerah perumahan dan/atau daerah } \\
\text { pertanian (dalam daerah perkotaan yang } \\
\text { terbatas) }\end{array}$ & Kecil & 30 \\
\hline 4 & $\begin{array}{l}\text { Jika terjadi genangan pada daerah yang } \\
\text { jarang penduduknya dan daerah yang tidak } \\
\text { produktif }\end{array}$ & Sangat Kecil & 0 \\
\hline
\end{tabular}

Sumber : Tata Cara Penyusunan Sistem Drainase Kota 2011

Tabel 3. Kriteria Gangguan Sosial dan Fasilitas Pemerintah

\begin{tabular}{|c|l|c|c|}
\hline No & \multicolumn{1}{|c|}{ Parameter } & Pengaruh/Kerugian & Nilai \\
\hline 1 & $\begin{array}{l}\text { Jika genangan air/banjir terjadi pada daerah } \\
\text { yang banyak pelayanan fasilitas sosial dan } \\
\text { fasilitas pemerintah }\end{array}$ & Tinggi & 100 \\
\hline 2 & $\begin{array}{l}\text { Jika genangan air/banjir terjadi di daerah } \\
\text { yang sedikit pelayanan fasilitas sosial dan } \\
\text { fasilitass pemerintah }\end{array}$ & Sedang & 65 \\
\hline 3 & $\begin{array}{l}\text { Jika genangan air/banjir mempengaruhi atau } \\
\text { terjadi di daerah yang pelayanan fasilitas } \\
\text { sosial dan fasilitas pemerintah terbatas }\end{array}$ & Kecil & 0 \\
\hline 4 & $\begin{array}{l}\text { Jika tidak ada fasilitas sosial dan fasilitas } \\
\text { pemerintah }\end{array}$ & Sangat Kecil & 0 \\
\hline
\end{tabular}

Sumber : Tata Cara Penyusunan Sistem Drainase Kota 2011

Tabel 4. Kriteria Kerugian dan Gangguan Transportasi

\begin{tabular}{|c|l|c|c|}
\hline No & \multicolumn{1}{|c|}{ Parameter } & Pengaruh/Kerugian & Nilai \\
\hline 1 & $\begin{array}{l}\text { Jika genangan air/banjir terjadi pada daerah } \\
\text { yang jaringan transportasinya padat. }\end{array}$ & Tinggi & 100 \\
\hline 2 & $\begin{array}{l}\text { Jika genangan air/banjir terjadi di daerah } \\
\text { yang jaringan transportasinya kurang padat. }\end{array}$ & Sedang & 65 \\
\hline 3 & $\begin{array}{l}\text { Jika genangan air/banjir mempengaruhi atau } \\
\text { terjadi di daerah yang jaringan transporta- } \\
\text { sinya terbatas. }\end{array}$ & Kecil & 30 \\
\hline 4 & Jika tidak ada jaringan jalan & Sangat Kecil & 0 \\
\hline
\end{tabular}

Sumber : Tata Cara Penyusunan Sistem Drainase Kota 2011 


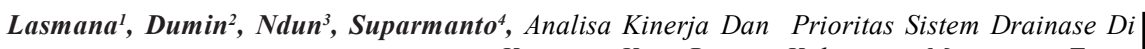
Kawasan Kota Borong Kabupaten Manggarai Timur

Tabel 5. Kriteria Kerugian Pada Daerah Perumahan

\begin{tabular}{|c|l|c|c|}
\hline No & \multicolumn{1}{|c|}{ Parameter } & Pengaruh/Kerugian & Nilai \\
\hline 1 & $\begin{array}{l}\text { Jika genangan air/banjr terjadi pada } \\
\text { perumahan padat sekali }\end{array}$ & Tinggi & 100 \\
\hline 2 & $\begin{array}{l}\text { Jika genangan air/banjir terjadi pada } \\
\text { perumahan yang kurang padat }\end{array}$ & Sedang & 30 \\
\hline 3 & $\begin{array}{l}\text { Jika genangan air/banjir mempengaruhi atau } \\
\text { terjadi di daerah yang hanya pada beberapa } \\
\text { bangunan perumahan }\end{array}$ & Kecil & 0 \\
\hline 4 & $\begin{array}{l}\text { Jika tidak ada perumahan pada daerah } \\
\text { genangan air/banjir }\end{array}$ & Sangat Kecil & \\
\hline
\end{tabular}

Sumber : Tata Cara Penyusunan Sistem Drainase Kota 2011

Tabel 6. Kriteria Kerugian hak Milik Pribadi

\begin{tabular}{|c|l|c|c|}
\hline No & \multicolumn{1}{|c|}{ Parameter } & Pengaruh/Kerugian & Nilai \\
\hline 1 & $\begin{array}{l}\text { Jika kerugian lebih dari } 80 \% \text { nilai milik } \\
\text { pribadi }\end{array}$ & Tinggi & 100 \\
\hline 2 & Jika kerugian $80 \%$ dari nilai milik pribadi & Sedang & 65 \\
\hline 3 & Jika kerugian kurang dari $40 \%$ milik pribadi & Kecil & 30 \\
\hline 4 & Tidak ada kerugian milik pribadi & Sangat Kecil & 0 \\
\hline
\end{tabular}

Sumber : Tata Cara Penyusunan Sistem Drainase Kota 2011

Jumlah nilai dari keenam kriteria tersebut di atas berkisar antar $0 \mathrm{~s} / \mathrm{d} 600$. Nilai tertinggi merupakan kawasan dengan prioritas utama, makin rendah nilainya makin rendah pula prioritasnya.

\section{Paramater Kapasitas dan Kerusakan Jaringan Drainase}

Tingkat kapasitas dan kerusakan jaringan menunjukkan secara utuh tentang kondisi fisik jaringan drainase, yaitu mengenai kapasitas dan kondisi fisik jaringan yang dibagi menjadi beberapa komponen, yaitu terdiri dari saluran penerima (interseptor drain ), saluran pengum- pul (colector drain), saluran pembawa (conveyor drain), saluran induk (main drain) dan bangunan pelengkap lainnya seperti goronggorong, dan bangunan pertemuan (bak kontrol). Setiap komponen memberikan kontribusi terhadap kondisi fisik jaringan secara keseluruhan. Bobot setiap komponen disusun atas besarnya pengaruh terhadap terjaminnya layanan pengaliran air genangan (pedoman penilaian jaringan drainase). Dalam hal ini penulis mengambil rujukan dengan menganalogikan penilaian fisik jaringan irigasi dari Subdit EPMP Direktorat Bina Program Ditjen Air. Jakarta, seperti ditunjukkan pada Gambar 2.4. 
Penilaian kondisi jaringan drainase keseluruhan dilakukan dengan menghitung kondisi saluran induk, saluran pembawa, saluran pengumpul, saluran penerima, gorong-gorong, dan Sumur Resapan Air Hujan ( Sobriyah, 2005). Seperti ditunjukkan pada rumus-rumus sebagai berikut : Kondisi sistem jaringan pada sub sistem, dihitung dengan rumus :
Dengan :

$\mathrm{J}=$ Kondisi sistem jaringan (\%).

$\mathrm{Si}=$ Kondisi saluran induk $(\%)$

$\mathrm{Spe}=$ Kondisi saluran pengumpul $(\%)$

$\mathrm{Spi}=$ Kondisi saluran penerima $(\%)$

$\mathrm{Gr}=$ Kondisi gorong-gorong $(\%)$

$\mathrm{Bp}=$ Kondisi bangunan pertemuan (\%)

$\mathrm{Sr}=$ Kondisi sumur resapan $(\%)$

$$
\mathrm{J}=\mathrm{Si}+\mathrm{Spe}+\mathrm{Spi}+\mathrm{Gr}+\mathrm{Bp}+\mathrm{Sr}
$$

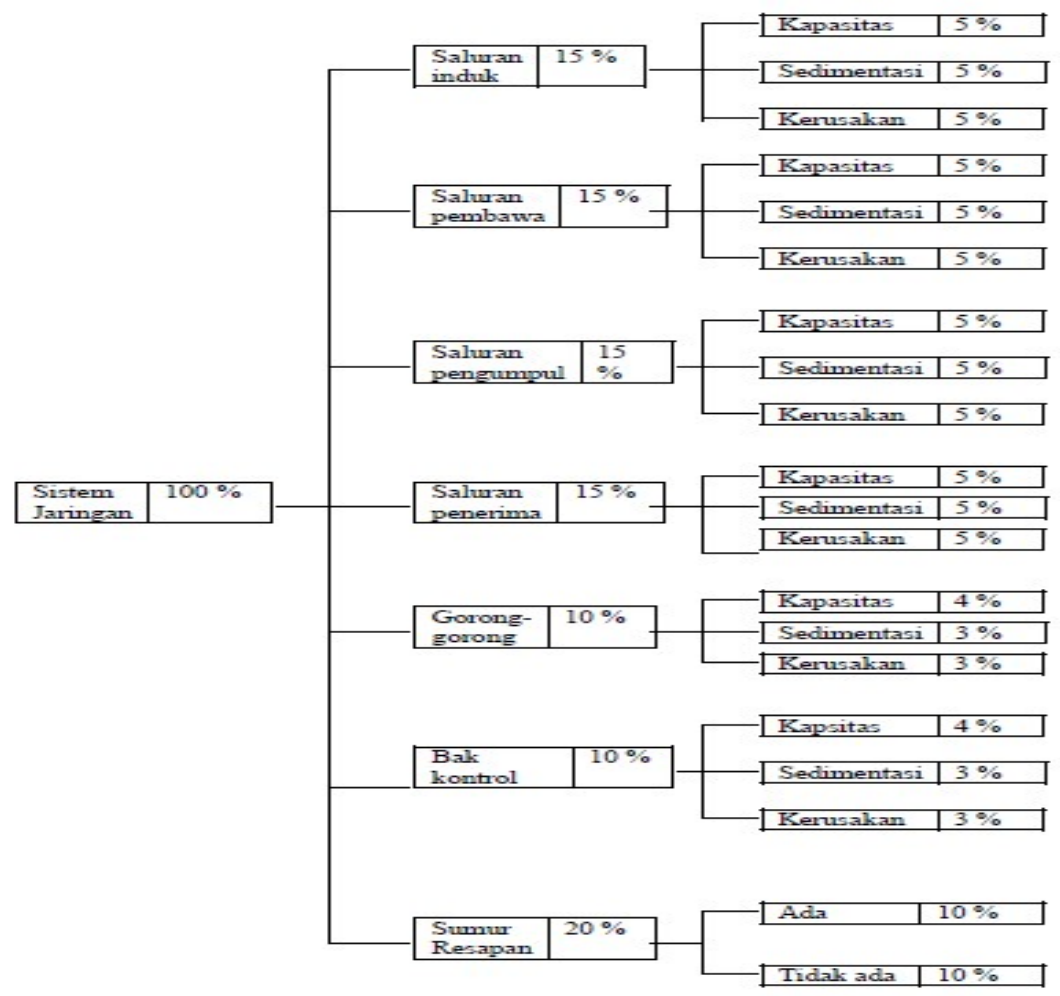

Gambar 4. Distribusi Komponen dan Bobot pada Jaringan Drainase

Tabel 7. Pedoman Penilaian Jaringan Irigasi Badan Saluran

\begin{tabular}{|l|l|l|l|}
\hline \multirow{2}{*}{ Kriteria } & \multicolumn{3}{|c|}{ Kondisi Bangunan } \\
\cline { 2 - 4 } & \multicolumn{1}{|c|}{ Baik } & \multicolumn{1}{c|}{ Cukup } & \multicolumn{1}{c|}{ Rusak } \\
\hline Kapasitas (Dimensi & Memenuhi kapasitas & Memenuhi kapasitas & Tidak memenuhi \\
Penampang melintang & pembebanan sesuai & pembebanan sesuai de- & kapasitas pembe- \\
& dengan perencanaan dan & ngan perencanaan dan & banan sesuai dengan \\
& mempunyai tinggi jagaag & mempunyai tinggi ja- & perencanaan. Kondisi \\
& yang cukup untuk men- & gaan yang sesuai de- & rata-rata diatas 0\% - \\
& cegah air melimpah. & ngan nuka air maksi- & $49 \%$. \\
& Kondisi rata-rata diatas & mum. Kondisi rata-rata & \\
& $80 \%-100 \%$. & diatas 50\% - 79\% & \\
\hline
\end{tabular}


Lasmana ${ }^{1}$, Dumin $^{2}, \mathrm{Ndun}^{3}$, Suparmanto $^{4}$, Analisa Kinerja Dan Prioritas Sistem Drainase Di Kawasan Kota Borong Kabupaten Manggarai Timur

\begin{tabular}{|l|l|l|l|}
\hline Pengendapan/Sedimen & $\begin{array}{l}\text { Tidak ada pengendapan } \\
\text { yang berpengaruh } \\
\text { terhadap kapasitas } \\
\text { rencana saluran. Kondisi } \\
\text { rata-rata diatas 80\%- } \\
100 \% .\end{array}$ & $\begin{array}{l}\text { Ada endapan yang } \\
\text { berpengaruh terhadap } \\
\text { kapasitas rencana } \\
\text { saluran }(<30 \%) . \text { Kondisi } \\
\text { rata-rata diatas 50\% }- \\
79 \% .\end{array}$ & $\begin{array}{l}\text { Adapan yang } \\
\text { terhadap kapasitas } \\
\text { rencana saluran } \\
(>30 \%) . \text { Kondisi } \\
\text { rata-rata diatas } 0 \%- \\
49 \% .\end{array}$ \\
\hline Kerusakan & $\begin{array}{l}\text { Profil saluran keadaan- } \\
\text { nya masih baik/tidak ada } \\
\text { kerusakan. Kondisi } \\
\text { rata-rata diatas 80\% }- \\
100 \% .\end{array}$ & $\begin{array}{l}\text { Profil saluran keadaan- } \\
\text { nya ada kerusakan } \\
(<30 \%) . \text { Kondisi rata- } \\
\text { rata diatas 50\% - 79\%. }\end{array}$ & $\begin{array}{l}\text { Profil saluran kea- } \\
\text { daannya ada keru- } \\
\text { sakan }(>30 \%) . \text { Kon- } \\
\text { disi rata-rata diatas } \\
0 \%-49 \% .\end{array}$ \\
\hline
\end{tabular}

Sumber : Adopsi Pedoman Penilaian Jaringan Irigasi dari Subdit EPMP Dit. Bina Program, Ditjen Air dalam Sobariyah, 2005.

\section{METODOLOGI PENELITIAN}

Beberapa aspek yang terkait dengan metode penelitian yang akan digunakan untuk mencapai tujuan dari penelitian ini. Beberapa aspek tersebut meliputi : lokasi dan waktu penelitian, metode penelitian, sampling dan teknik pengambilan sampel, sumber data dan teknik pengambilan data, teknik pengolahan data dan teknik analisis data.

\section{Lokasi Penelitian}

Obyek penelitian yaitu Kawasan Kota Borong Kabupaten Manggarai Timur.

\section{Metode Penelitian}

Pada studi ini metode yang dipakai adalah Deskriptif Evaluatif, yaitu metode studi yang mengevaluasi kondisi obyektif / apa adanya pada suatu keadaan yang sedang menjadi obyek studi ( Supriharyono, 2002 ). Analisis yang dipergunakan dalam penelitian ini adalah analisis diskriptif kualitatif yaitu penelitian yang bertujuan menggambarkan secara tepat sifatsifat suatu individu, keadaan atau gejala tertentu pada lokasi penelitian.

\section{Sumber Data dan Teknik Pengumpulan Data}

Data yang dipakai sebagai bahan analisis dalam penelitian ini adalah data primer dan data sekunder.

\section{Analisis}

Analisis yang dilakukan meliputi hal-hal sebagai berikut : Analisis kondisi eksisting sistem jaringan drainase, Analisis Kebutuhan dan kinerja sistem saluran drainase, Penyusun Usulan Prioritas kegiatan penanganan banjir dan genangan di kawasan kota Borong.

\section{PEMBAHASAN \\ Kondisi Geografis}

Secara astronomis wilayah Kabupaten Manggarai Timur terletak Antara 08 .14' $09^{\circ} .00$ Lintang Selatan dan $120^{\circ} .20^{\prime}-120^{\circ} .55^{\circ} \circ$ Bujur Timur. Batas-batas wilayah sebagai berikut: Sebelah Timur berbatasan dengan Kabupaten Ngada, Sebelah Barat berbatasan dengan Kabupaten Manggarai, Sebelah Utara berbatasan dengan Laut Flores, Sebelah Selatan berbatasan dengan Laut Sawu. Wilayah administrasi pemerintahan berdasarkan data statistik tahun 2016 terdiri dari 6 buah kecamatan.

Secara Administratif pemerintahan wilayah Kota Borong terdapat di Kecamatan Borong. Desa/Kelurahan sebagai berikut Desa Golokantar, Desa Nangalabang, Kelurahan Kota Ndora, Kelurahan Rana Loba, Sebagian Desa Gurung Liwut, dengan luas $6810 \mathrm{Ha}$ Adapun batasan wilayah Kota Borong: Sebelah Timur berbatasan dengan Kecamatan Kota Komba, Sebelah Barat berbatasan dengan Kecamatan 


\section{\begin{tabular}{l|l|llll} 
& 74 & JUTEKS Jurnal Teknik Sipil Volume 2 & Nomor 1 April 2017
\end{tabular}}

Satar Mese Kabupaten Manggarai, Sebelah dan Kecamatan Pocoranaka, Sebelah Selatan Utara berbatasan dengan Desa Gurung Liwut berbatasan dengan Laut Sawu.
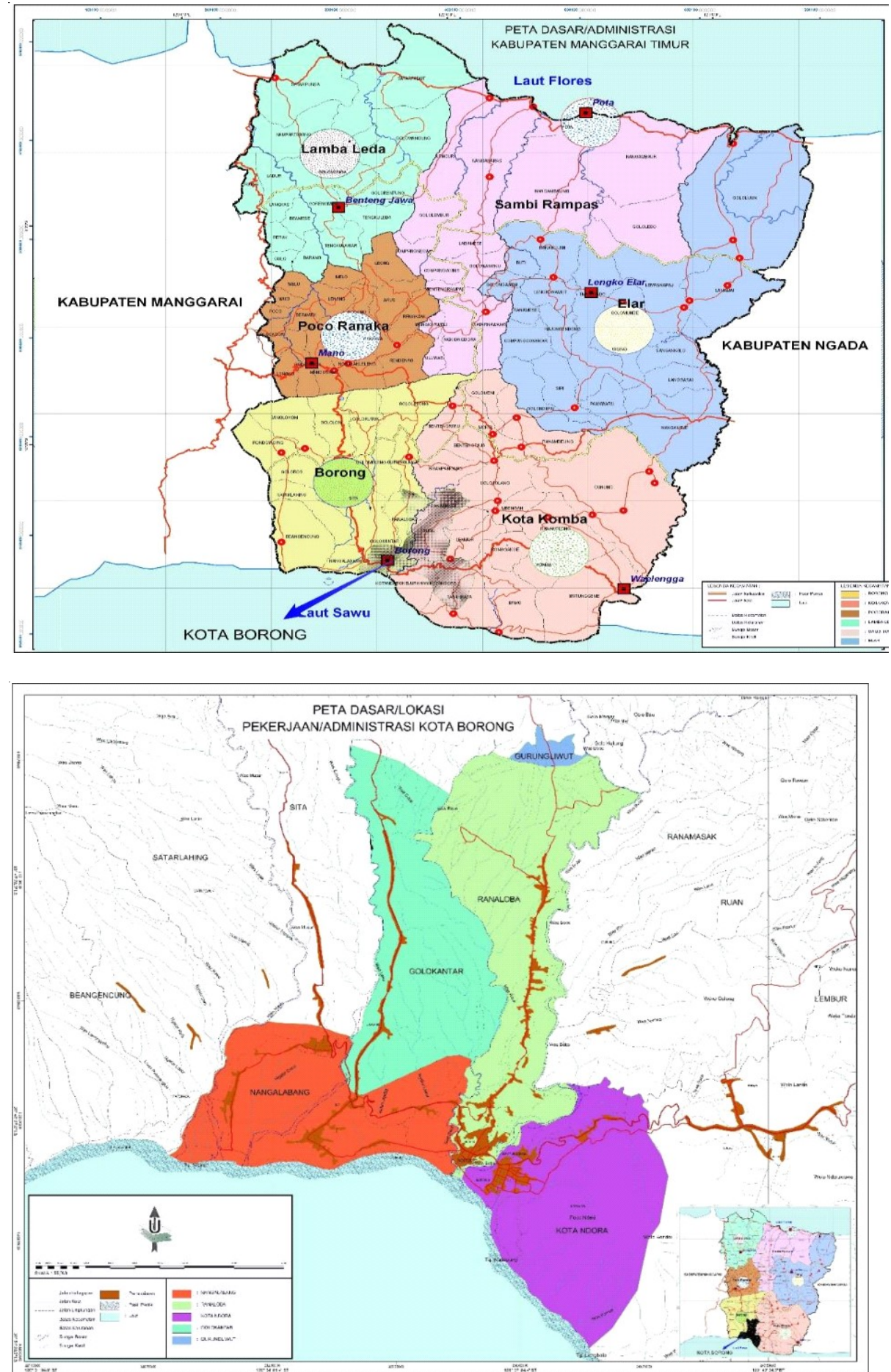

Gambar 5. Peta Dasar/Administrasi Kabupaten Manggarai Timur dan Kota Borong 


\section{Kondisi Drainase Eksisting dan Permasalahan}

Kondisi topografi Kawasan Kota Borong sebagian besar relatif datar dan bergelombang, terutama pada bagian selatan, oleh karena itu saluran sungai yang mengalir di bagian wilayah ini sering meluap apabila pada kondisi pasang sungai atau debit air hujan yang tinggi.

Saluran drainase untuk kawasan-kawasan pemukiman belum tertata dengan baik bahkan ada yang belum memiliki drainase, masyarakat membuang limbah ataupun air kotor yang mereka hasilkan ke saluran terdekat ataupun sungai sehingga bentuk jaringan drainase yang ada di Kota Borong masih belum diketemukan. Jalan-jalan di Kawasan Kota Borong belum dilengkapi sistem drainase yang permanen, hanya sebagian kecil saja terutama di Jalan Negara dan Jalan Kabupaten menuju ke arah Santarlehong yang telah dibangun saluran pembuangan meskipun kondisi kurang memadai, sebagian besar lainnya masih berupa saluran dari tanah.

\section{Identifikasi Kondisi Drainase Makro dan Mikro}

Dari hasil identifikasi kondisi drainase (makro) di wilayah Kota Borong dialiri oleh 4 (empat) sungai besar yang aliran airnya mengalir sepanjang tahun yaitu : Sungai Wae Bobo, Sungai Wae Reca, Sungai Wae Laku, Sungai Wae Musur.

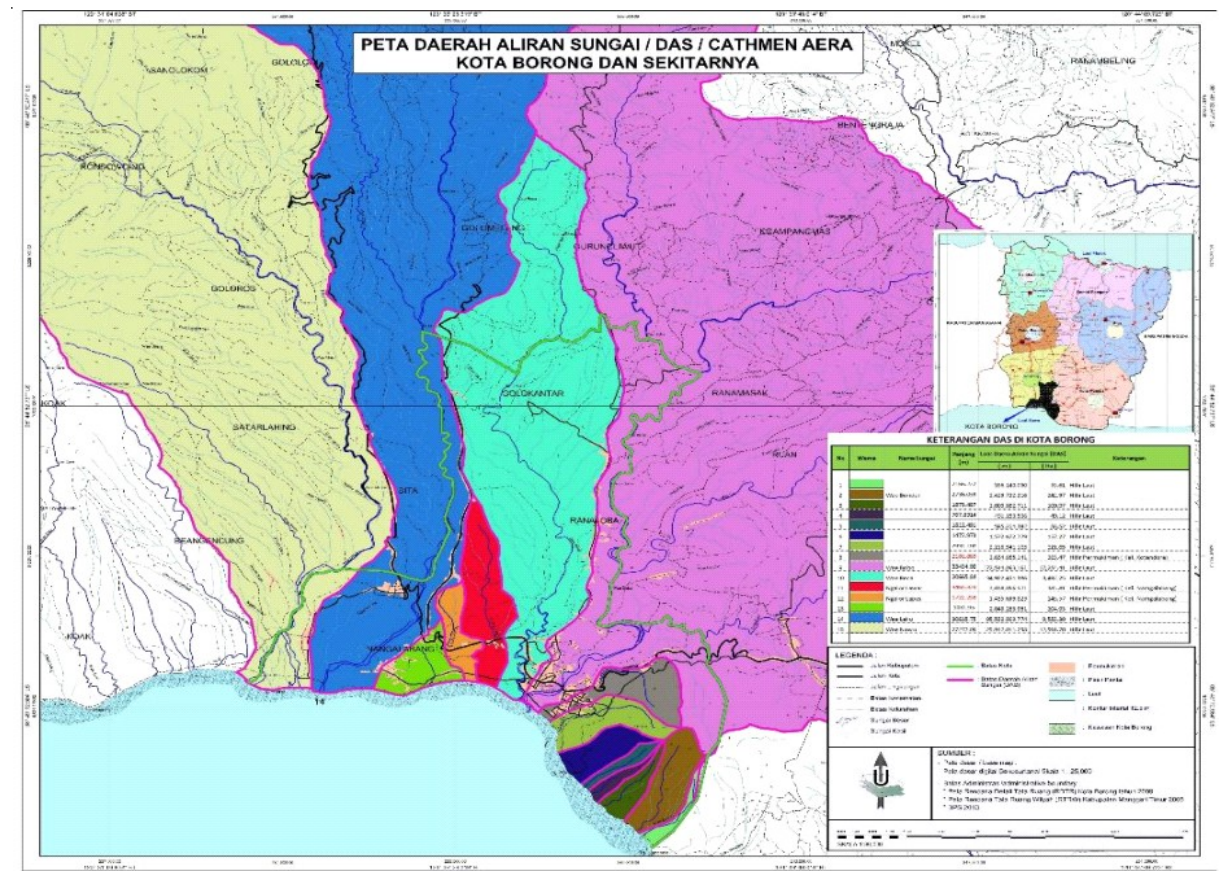

Gambar 6. Peta Daerah Aliran Sungai (DAS) dalam Wilayah Kota Borong

Saluran Drainase Mikro Eksisting pada umumnya saluran drainase yang ada belum dibuat dengan perencanaan yang baik. Saluran drainase eksisting masih bersifat parsial (setempat - setempat). Kondisi ini tentunya tidak dapat menyelesaikan masalah banjir dan genangan yang terjadi di kawasan Kota Borong.

Berikut ini hasil identifikasi saluran drainase beberapa kawasan di Kota Borong yaitu: 
\begin{tabular}{l|l|llll}
$\square$ & 76 & JUTEKS Jurnal Teknik Sipil Volume 2 & Nomor 1 & April 2017
\end{tabular}

Tabel 8. Hasil Identifikasi kondisi Saluran dan genangan di Kawasan Kota Borong

\begin{tabular}{|c|c|c|c|c|c|c|c|}
\hline \multirow{3}{*}{$\begin{array}{c}\text { No } \\
\text { Genagan }\end{array}$} & \multirow{3}{*}{ Lokasi Genangan } & \multirow{3}{*}{$\begin{array}{c}\text { Desa/Keluraha } \\
\mathrm{n}\end{array}$} & \multicolumn{4}{|c|}{ Besarnya Genangan } & \multirow[b]{3}{*}{ Penyebab Terjadinnya Genangan } \\
\hline & & & Luas & Tinggi & Lama & Frekuensi & \\
\hline & & & (Ha) & $(\mathrm{m})$ & (Jam) & & \\
\hline \multirow{3}{*}{ DG 1} & \multirow{3}{*}{$\begin{array}{c}\text { Daerah Pasar } \\
\text { Borong }\end{array}$} & \multirow{3}{*}{$\begin{array}{c}\text { Kelurahan } \\
\text { Ranaloba }\end{array}$} & \multirow{3}{*}{0.5} & \multirow{3}{*}{0.3} & \multirow{3}{*}{48} & \multirow{3}{*}{$\begin{array}{l}\text { sangat } \\
\text { sering }\end{array}$} & Saluran tidak memperhatikan elevasi \\
\hline & & & & & & & sedimentasi saluran \\
\hline & & & & & & & saluran di atas badan jalan \\
\hline \multirow{2}{*}{ DG 2} & \multirow{2}{*}{$\begin{array}{c}\text { Daerah Pasar } \\
\text { Borong/Terminal }\end{array}$} & \multirow{2}{*}{$\begin{array}{c}\text { Kelurahan } \\
\text { Ranaloba }\end{array}$} & \multirow{2}{*}{0.2} & \multirow{2}{*}{0.5} & \multirow{2}{*}{48} & \multirow{2}{*}{$\begin{array}{l}\text { sangat } \\
\text { sering }\end{array}$} & Saluran tidak memperhatikan elevasi \\
\hline & & & & & & & sedimentasi saluran \\
\hline \multirow{2}{*}{ DG 3} & \multirow{2}{*}{ Depan Koramil } & \multirow{2}{*}{$\begin{array}{c}\text { Kelurahan } \\
\text { Ranaloba }\end{array}$} & \multirow{2}{*}{0.1} & \multirow{2}{*}{0.5} & \multirow{2}{*}{48} & \multirow{2}{*}{ sering } & Saluran tidak memperhatikan elevasi \\
\hline & & & & & & & Saluran diatas badan jalan \\
\hline \multirow{2}{*}{ DG 4} & \multirow{2}{*}{$\begin{array}{l}\text { Perempatan di } \\
\text { Kampung Bugis }\end{array}$} & \multirow{2}{*}{$\begin{array}{c}\text { Kelurahan } \\
\text { Ranaloba }\end{array}$} & \multirow{2}{*}{0.2} & \multirow{2}{*}{0.2} & \multirow{2}{*}{24} & \multirow{2}{*}{ sering } & Saluran tidak memperhatikan elevasi \\
\hline & & & & & & & limpasan dari bukit \\
\hline \multirow{3}{*}{ DG 5} & \multirow{3}{*}{$\begin{array}{c}\text { Jalan Sukun } \\
\text { (kampung bugis } \\
\text { peji depan kios } \\
\text { warga) }\end{array}$} & & & & & & Saluran tidak memperhatikan elevasi \\
\hline & & Ranaloba & 0.2 & 0.2 & 24 & sering & Sedimentasi saluran \\
\hline & & & & & & & limpasan dari bukit \\
\hline DG 6 & $\begin{array}{l}\text { Jalan Srikaya } \\
\text { (depan Kantor }\end{array}$ & $\begin{array}{l}\text { Kelurahan } \\
\text { Kota Ndora }\end{array}$ & 0.4 & 0.5 & 48 & sering & Saluran tidak memperhatikan elevasi \\
\hline DG 7 & $\begin{array}{l}\text { Jalan Srikaya } \\
\text { (depan Masjid }\end{array}$ & Kelurahan & 0.5 & 0.5 & 62 & sangat & Tidak ada saluran \\
\hline & Kota Ndora) & Kota Ndora & & & & sering & saluran tersumbat \\
\hline DG 8 & $\begin{array}{c}\text { Jalan Sukun } \\
\text { (masuk dari jalan }\end{array}$ & Kelurahan & 0.3 & 0.2 & 24 & sering & Saluran tidak memperhatikan elevasi \\
\hline & negara) & Ranaloba & & & & & Saluran diatas badan jalan \\
\hline
\end{tabular}

Sumber : Survey Lapangan

Berdasarkan analisis Kinerja didapat hasil kondisi jaringan drainase pada DG1 seperti disajikan pada Tabel dibawah ini. Untuk Sub Sistem yang lain dihitung analog dengan analisis pada sub sistem DG1.

Tabel 9. Bobot Komponen

\begin{tabular}{|c|l|r|}
\hline No & \multicolumn{1}{|c|}{ Komponen } & Bobot (\%) \\
\hline 1 & Saluran Induk & 15 \\
\hline 2 & Saluran Pembawa & 15 \\
\hline 3 & Saluran Pengumpul & 15 \\
\hline 4 & Saluran Penerima & 15 \\
\hline 5 & Gorong-Gorong & 10 \\
\hline 6 & Bak Kontrol & 10 \\
\hline 7 & Sumur Resapan & 20 \\
\hline \multicolumn{2}{|c|}{ Jumlah } & $\mathbf{1 0 0}$ \\
\hline
\end{tabular}


Tabel 10. Bobot Komponen dan Kriteria Jaringan Drainase (DG1)

\begin{tabular}{|c|c|c|c|c|c|c|c|}
\hline \multirow[b]{2}{*}{ No } & \multirow[b]{2}{*}{ Komponen } & \multirow[b]{2}{*}{$\begin{array}{c}\text { Bobot } \\
(\%)\end{array}$} & \multicolumn{5}{|c|}{ Bobot Kriteria } \\
\hline & & & Kapasitas & Sedimentasi & Kerusakan & ada & $\begin{array}{c}\text { tidak } \\
\text { ada }\end{array}$ \\
\hline 1 & Saluran Induk & 15 & 5 & 5 & 5 & & \\
\hline 2 & Saluran Pembawa & 15 & 5 & 5 & 5 & & \\
\hline 3 & Saluran Pengumpul & 15 & 5 & 5 & 5 & & \\
\hline 4 & Saluran Penerima & 15 & 5 & 5 & 5 & & \\
\hline 5 & Gorong-Gorong & 10 & 4 & 3 & 3 & & \\
\hline 6 & Bak Kontrol & 10 & 4 & 3 & 3 & & \\
\hline 7 & Sumur Resapan & 20 & & & & 10 & 10 \\
\hline & Jumlah & 100 & & & & & \\
\hline
\end{tabular}

Sumber : Hasil Analisa

Tabel 11. Hasil Penilaian Kinerja Kondisi Jaringan Drainase (DG1)

\begin{tabular}{|c|c|c|c|c|c|c|c|}
\hline \multirow[b]{2}{*}{ No } & \multirow[b]{2}{*}{ Komponen } & \multirow{2}{*}{$\begin{array}{c}\text { Bobot } \\
(\%)\end{array}$} & \multicolumn{5}{|c|}{ Bobot Kriteria } \\
\hline & & & Kapasitas & Sedimentasi & Kerusakan & ada & $\begin{array}{c}\text { tidak } \\
\text { ada }\end{array}$ \\
\hline 1 & Saluran Induk & 15 & 5 & 5 & 5 & & \\
\hline 2 & Saluran Pembawa & 12 & 4 & 4 & 4.30 & & \\
\hline 3 & Saluran Pengumpul & 12 & 4 & 4 & 4 & & \\
\hline 4 & Saluran Penerima & 14 & 5 & 4 & 5 & & \\
\hline 5 & Gorong-Gorong & 5 & 2 & 1.23 & 2 & & \\
\hline 6 & Bak Kontrol & 5 & 2 & 1 & 2 & & \\
\hline 7 & Sumur Resapan & 0 & & & & 0 & 0 \\
\hline & Jumlah & 63,53 & & & & & \\
\hline
\end{tabular}

Sumber : Hasil Analisa

\section{Penentuan Skala Prioritas Penangan}

Penentuan menurut jenis kriteria prioritas digunakan untuk menentukan hal-hal apa saja yang dianggap memiliki pengaruh dominan dalam menentukan urutan penanganan daerah genangan yang terjadi dilokasi studi. Untuk itu dalam penentuan skala prioritas panganganan daerah genangan maka, ditentukan berdasarkan kriteria yang telah ditetapkan oleh Tata Cara Penyusunan Drainase Perkotaan yang dikeluarkan oleh Kementrian PU pada tahun 2012. yaitu :
1.Parameter genangan, meliputi tinggi genangan, luas genangan, frekuensi genangan dalam satu tahun dan lama genangan terjadi. 2.Parameter ekonomi, dihitung perkiraan kerugian atas fasilitas ekonomi yang ada, seperti : kawasan industri, fasum fasos, perkantoran, perumahan, daerah pertanian dan pertamanan.

3.Parameter gangguan sosial dan fasilitas pemerintah, seperti : Kesehatan masyarakat, keresahan sosial dan kerusakan lingkungan dan kerusakan fasilitas pemerintah. Kriteria gangguan sosial dan fasilitas pemerintah. 


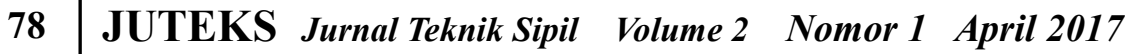

4.Parameter kerugian dan gangguan 5.Parameter kerugian pada daerah perumahan. transportasi. Kriteria kerugian dan gangguan 6 .Parameter kerugian hak milik pribadi/rumah transportasi. tangga.

Tabel 12. Hasil perhitungan Kriteria Parameter Genangan untuk setiap daerah genangan yang ada

\begin{tabular}{|l|l|c|c|c|c|c|}
\hline No & \multicolumn{1}{|c|}{$\begin{array}{c}\text { Daerah } \\
\text { Genangan }\end{array}$} & $\begin{array}{c}\text { Tinggi } \\
\text { Genangan }\end{array}$ & $\begin{array}{c}\text { Luas } \\
\text { Genangan }\end{array}$ & $\begin{array}{c}\text { Lamanya } \\
\text { Genangan }\end{array}$ & $\begin{array}{c}\text { Frekuensi } \\
\text { Genangan }\end{array}$ & $\begin{array}{c}\text { Jum- } \\
\text { lah }\end{array}$ \\
\hline DG1 & Daerah Pasar Borong & 26.25 & 0 & 20 & 15 & 61.25 \\
\hline DG2 & Daerah Pasar Borong/Terminal & 26.25 & 0 & 20 & 15 & 61.25 \\
\hline DG3 & Depan Koramil & 26.25 & 0 & 20 & 15 & 61.25 \\
\hline DG4 & Perempatan di Kapung Bugis & 17.5 & 0 & 20 & 15 & 52.5 \\
\hline DG5 & $\begin{array}{l}\text { Jalan Sukun (kampung bugis peji } \\
\text { depan kios warga) }\end{array}$ & 17.5 & 0 & 20 & 15 & 52.5 \\
\hline DG6 & $\begin{array}{l}\text { Jalan Srikaya (depan Kantor } \\
\text { DPRD) }\end{array}$ & 26.25 & 0 & 20 & 15 & 61.25 \\
\hline DG7 & $\begin{array}{l}\text { Jalan Srikaya (depan Masjid Kota } \\
\text { Ndora) }\end{array}$ & 26.25 & 0 & 20 & 15 & 61.25 \\
\hline DG8 & $\begin{array}{l}\text { Jalan Sukun (masuk dari jalan } \\
\text { negara) }\end{array}$ & 17.5 & 0 & 20 & 15 & 52.5 \\
\hline
\end{tabular}

Sumber : Hasil Analisa

\section{Penentuan Kawasan Prioritas}

Perhitungan penentuan kawasan prioritas ini dilakukan dengan melihat kondisi eksisting kawasan dan hasil wawancara dengan masyarakat yang mana dilakukan analisis untuk mengetahui berbagai kemungkinan kerugian yang ditimbulkan akibat terjadinya genangan pada daerah/kawasan tersebut.

Hasil analisis kawasan prioritas yang didapatkan diharapkan nantinya dapat menjadi kawasan acuan untuk dilakukan perbaikan ataupun pembangunan fisik drainase. Tabel dibawah ini memperlihatkan Perhitungan Pembobotan Kawasan Prioritas berdasarkan parameter yang ada. Tabel 13 memperlihatkan hasil Perhitungan Pembobotan Kawasan Prioritas berdasarkan parameter yang ada.

\section{Klasifikasi Kawasan Prioritas}

Dari hasil skoring yang telah didapatkan tersebut dibuat klasifikasi nilai berdasarkan nilai tertinggi sampai dengan nilai terendah. Kawasan dengan nilai tertinggi selanjutnya disebut sebagai kawasan prioritas I (pertama), kawasan dengan nilai tertinggi kedua adalah kawasan prioritas II (Kedua), kawasan dengan nilai tertinggi ketiga adalah kawasan prioritas III (ketiga) dan seterusnya sampai dengan kawasan prioritas terakhir.

Berdasarkan ketentuan tersebut maka dapat diketahui bahwa kawasan Daerah Pasar Borong terpilih sebagai Kawasan prioritas 1 (satu) dan Kawasan Daerah pasar Borong / Terminal sebagai kawasan prioritas 2 (dua) selanjutnya dapat dilihat dalam tabel 14 . 
Tabel 13. Hasil Perhitungan Pembobotan Kawasan Prioritas berdasarkan parameter yang ada.

\begin{tabular}{|c|c|c|c|c|c|c|c|c|}
\hline No & $\begin{array}{c}\text { Daerah } \\
\text { Genangan }\end{array}$ & $\begin{array}{c}\text { Kri- } \\
\text { teria } \\
\text { Para- } \\
\text { meter } \\
\text { Genangan }\end{array}$ & $\begin{array}{c}\text { Kri- } \\
\text { teria } \\
\text { Keru- } \\
\text { gian } \\
\text { Eko- } \\
\text { nomi }\end{array}$ & $\begin{array}{c}\text { Kriteria } \\
\text { Kerugian } \\
\text { Gangguan } \\
\text { sosial } \\
\text { dan fasilitas } \\
\text { Pemerintah }\end{array}$ & $\begin{array}{c}\text { Kriteria } \\
\text { Kerugian } \\
\text { dan } \\
\text { Gangguan } \\
\text { Trans- } \\
\text { portasi }\end{array}$ & $\begin{array}{c}\text { Kriteria } \\
\text { Kerugian } \\
\text { pada } \\
\text { daerah } \\
\text { Peru- } \\
\text { mahan }\end{array}$ & $\begin{array}{c}\text { Kriteria } \\
\text { Keru- } \\
\text { gian } \\
\text { Hak } \\
\text { Milik } \\
\text { Pribadi }\end{array}$ & $\begin{array}{c}\text { Jum- } \\
\text { lah }\end{array}$ \\
\hline DG1 & Daerah Pasar Borong & 61.25 & 100 & 100 & 65 & 65 & 65 & 456.25 \\
\hline DG2 & $\begin{array}{l}\text { Daerah Pasar Borong/ } \\
\text { Terminal }\end{array}$ & 61.25 & 65 & 100 & 65 & 65 & 65 & 421.25 \\
\hline DG3 & Depan Koramil & 61.25 & 30 & 65 & 65 & 65 & 65 & 351.25 \\
\hline DG4 & $\begin{array}{l}\text { Perempatan di Kampung } \\
\text { Bugis }\end{array}$ & 52.5 & 30 & 30 & 30 & 65 & 30 & 237.5 \\
\hline DG5 & $\begin{array}{l}\text { Jalan Sukun (kampung bugis } \\
\text { peji depan kios warga) }\end{array}$ & 52.5 & 30 & 30 & 30 & 65 & 30 & 237.5 \\
\hline DG6 & $\begin{array}{l}\text { Jalan Srikaya (depan Kantor } \\
\text { DPRD) }\end{array}$ & 61.25 & 30 & 65 & 65 & 65 & 65 & 351.25 \\
\hline DG7 & $\begin{array}{l}\text { Jalan Srikaya (depan Masjid } \\
\text { Kota Ndora) }\end{array}$ & 61.25 & 30 & 65 & 65 & 65 & 65 & 351.25 \\
\hline DG8 & $\begin{array}{l}\text { Jalan Sukun (masuk dari } \\
\text { jalan negara) }\end{array}$ & 52.5 & 30 & 30 & 30 & 65 & 30 & 237.5 \\
\hline
\end{tabular}

Sumber : Hasil Analisa

Tabel 14. Klasifikasi Kawasan Prioritas berdasarkan hasil skoring

\begin{tabular}{|c|l|c|c|}
\hline No & \multicolumn{1}{|c|}{ Daerah Genangan } & $\begin{array}{c}\text { Urutan } \\
\text { Prioritas } \\
\text { Penanganan }\end{array}$ & $\begin{array}{c}\text { Penentuan } \\
\text { Daerah } \\
\text { Prioritas }\end{array}$ \\
\hline 1 & Daerah Pasar Borong & 1 & 456.25 \\
\hline 2 & Daerah Pasar Borong/Terminal & 2 & 421.25 \\
\hline 3 & Depan Koramil & 3 & 351.25 \\
\hline 4 & Jalan Srikaya (depan Masjid Kota Ndora) & 4 & 351.25 \\
\hline 5 & Jalan Srikaya (depan Kantor DPRD) & 5 & 351.25 \\
\hline 6 & Jalan Sukun (masuk dari jalan negara) & 6 & 237.5 \\
\hline 7 & Jalan Sukun (kampung bugis peji depan kios warga) & 7 & 237.5 \\
\hline 8 & Perempatan di Kapung Bugis & 8 & 237.5 \\
\hline
\end{tabular}

Sumber : Hasil Analisa 


\section{\begin{tabular}{l|llll}
80 & JUTEKS Jurnal Teknik Sipil Volume 2 & Nomor 1 April 2017
\end{tabular}}

Rekomendasi Penanganan Kawasan Prioritas

Berdasarkan urutan prioritas penanganan selanjutnya disusun usulan rekomendasi penanganan untuk masing-masing daerah genangan sehingga dapat menjawab permasalahan yang terjadi pada masing-masing daerah genangan. Dalam membuat rekomendasi penanganan kawasan dilakukan dengan memperhatikan konsep Eco drain.

\begin{tabular}{|c|c|c|c|c|}
\hline No & Daerah Genangan & $\begin{array}{c}\text { Urutan } \\
\text { Prioritas } \\
\text { Penanganan }\end{array}$ & $\begin{array}{l}\text { Penentuan } \\
\text { Daerah } \\
\text { Prioritas }\end{array}$ & $\begin{array}{l}\text { Rekomendasi } \\
\text { Penanganan } \\
\text { Kawasan Prioritas }\end{array}$ \\
\hline 1 & Daerah Pasar Borong & 1 & 456.25 & $\begin{array}{l}\text { Peninggian badan jalan } \\
\text { Perbaikan kapasitas saluran } \\
\text { dan elelvasi saluran } \\
\text { - Pembuatan saluran baru }\end{array}$ \\
\hline 2 & Daerah Pasar Borong/Terminal & 2 & 421.25 & $\begin{array}{l}\text { Peninggian badan jalan } \\
\text { Perbaikan kapasitas saluran } \\
\text { dan elelvasi saluran } \\
\text { - Pembuatan saluran baru }\end{array}$ \\
\hline 3 & Depan Koramil & 3 & 351.25 & $\begin{array}{l}\text { Peninggian badan jalan } \\
\text { - Perbaikan kapasitas saluran } \\
\text { dan elelvasi saluran }\end{array}$ \\
\hline 4 & $\begin{array}{l}\text { Jalan Srikaya (depan Masjid Kota } \\
\text { Ndora) }\end{array}$ & 5 & 316.25 & $\begin{array}{l}\text { Perbaikan kapasitas saluran } \\
\text { dan elelvasi saluran } \\
\text { - Pembuatan saluran baru }\end{array}$ \\
\hline 5 & $\begin{array}{l}\text { Jalan Srikaya (depan Kantor } \\
\text { DPRD) }\end{array}$ & 6 & 316.25 & $\begin{array}{l}\text { Perbaikan kapasitas saluran } \\
\text { dan elelvasi saluran }\end{array}$ \\
\hline 6 & $\begin{array}{l}\text { Jalan Sukun (masuk dari jalan } \\
\text { negara) }\end{array}$ & 8 & 237.5 & $\begin{array}{l}\text { Peninggian badan jalan } \\
\text { Perbaikan kapasitas saluran } \\
\text { dan elelvasi saluran } \\
\text { - Pembuatan saluran baru }\end{array}$ \\
\hline 7 & $\begin{array}{l}\text { Jalan Sukun (kampung bugis peji } \\
\text { depan kios warga) }\end{array}$ & 9 & 237.5 & $\begin{array}{l}\text { Peninggian badan jalan } \\
\text { - Perbaikan kapasitas saluran } \\
\text { dan elelvasi saluran } \\
\text { - Pembuatan saluran baru }\end{array}$ \\
\hline 8 & Perempatan di Kapung Bugis & 10 & 237.5 & $\begin{array}{l}\text { Perbaikan kapasitas saluran } \\
\text { dan elelvasi saluran }\end{array}$ \\
\hline
\end{tabular}

Sumber : Hasil Analisa 


\section{PENUTUP}

\section{Kesimpulan}

1.Saluran drainase kawasan yang ada masih bersifat parsial (setempat - setempat). Konstruksi saluran drainase tidak memperhatikan elevasi dan kemiringan saluran, sehingga menyebabkan sedimentasi pada saluran, ketinggian saluran dan bada jalan tidak sesuai.

2.Kinerja sistem jaringan drainase di kawasan Kota Borong relatif cukup, harus dilakukan pembangunan dan rehabilitasi badan saluran di beberapa tempat guna menanggulangi terjadinya banjir. Hal ini terlihat pada persentase kondisi sistem jaringan drainase di masingmasing sub sistem, yaitu kondisi di DG1 = $63,53 \%$, kondisi di DG2 $=66,50 \%$, konsisi di DG3 $=69 \%$, DG4 $=60 \%$, DG5 $=61,25 \%$, DG6 $=68.37 \%$, DG7 $=53,27 \%$ dan kondisi di DG8 $=60,71 \%$. Sedangkan hasil indentifikasi menunjukkan bahwa implementasi konsep drainase yang berkelanjutan dengan pembuatan Sumur Resapan Air Hujan belum dilaksanakan.

3.Dari hasil penentuan skala prioritas penanganan di peroleh urutan kawasan yang akan menjadi prioritas solusi penanganan banjir dan genangan kawasan, diperoleh prioritas pertama kawasan pasar borong dan selanjutnya, dengan dilakukannya, Peninggian badan jalan, Perbaikan kapasitas saluran dan elevasi saluran, Pembuatan saluran baru dan bila memungkinkan perlu dilakukan pembuatan sumur-sumur resapan.

\section{Saran}

1.Diharapkan penelitian ini dapat menjadi masukan bagi Pemerintah dan juga instansi terkait untuk lebih memperhatikan kondisi drainase wilayah perkotaan.

2.Untuk analisis selanjutnya perlu memperhitungkan penilaian terhadap indikator non fisik seperti peraturan dan manajemen pembangunan agar mendapatkan hasil yang mendekati kondisi sebenarnya.
3. Perlu analisis Teknis dalam menetapkan solusi dari permasalahan sistem drainase yang ada karena penelitian ini menetapkan solusi hanya dari kondisi fisik di lapangan.

\section{DAFTAR PUSTAKA}

Soemarto, C.D. (1989). Hidrologi Teknik. Usaha Nasional, Surabaya.

Asdak, C. (2001). Hidrologi dan Pengelolaan Daerah Aliran Sungai. Gadjah Mada University Press, Yogyakarta.

Departemen Pekerjaan Umum, Peraturan Menteri Pekerjaan Umum Nomor 32/PRT/ M/2007 tentang Pedoman Operasi dan Pemeliharaan Jaringan Irigasi, Jakarta.

Sobriyah. (2005), Sistem Pendukung Keputusan Pada Penentuan Prioritas Rehabilitasi Jaringan Irigasi di DIY. Gema Teknik Fakultas Teknik Universitas Sebelas Maret

Sobriyah dan Wignyasukarto, Budi. (2001), Peran Serta Masyarakat dalam Pengendalian Banjir untuk Mendukung Pelaksanaan Otonomi Daerah. Makalah pada Kongres VII dan PIT VIII Himpunan Ahli Teknik Hidraulik Indonesia (HATHI), Malang 2001.

Sunjoto. (1987), Sistem Drainase Air Hujan yang Berwawasan Lingkungan, Makalah Seminar Pengkajian Sistem Hidrologi dan Hidrolika, PAU Ilmu Teknik Universitas Gajah Mada.

Suripin. (2004). Sistem Drainase Perkotaan yang Berkelanjutan, Penerbit Andi, Jogyakarta. 